УДК 657.6:006.037(477)

JEL Classification: H83, M42

Doi: 10.31767/su. 3(86)2019.03.12

O. E. Lubenchenko,

DSc in Economics, Associate Professor,

Head of the National Center for Accounting and Audit,

National Academy of Statistics, Accounting and Audit,

E-mail: olga.Iubenchenko@gmail.com

ORCID: https://orcid.org/0000-0002-4209-8929

\title{
The Internal Standard "The Policy and Procedure of the System for Internal Quality Control of Audit Services"
}

New Laws of Ukraine "On Accounting and Financial Reporting in Ukraine" and "On Audit of Financial Statements and Auditing" require the enhanced responsibility of auditors for auditing results. Creation of the body of public oversight over the auditing requires the continuing improvement of the internal control system through implementing internal company standards. The article proposes the elaborated procedure and key components of the internal standard "The Policy and Procedure of the System for Internal Quality Control of Audit Services".

The structure of the internal audit includes the following sections: glossary of terminology; leadership responsibilities for quality within the audit firm; ethical requirements; acceptance and continuance of client relationships; human resources; engagement performance (work documents on performance of previous engagement procedures, on planning of auditing engagements, on final procedures, other work documents); monitoring of quality control system and individual engagements; appendices. For understanding of International Standards of Auditing, the preamble of the internal standard should contain key notions and definitions. An important aspect is recording of issues creating the appropriate environment for control: style and essential principles of the audit firm management; organizational structure and specialization of the audit firm; sharing of responsibility and authorities of management and other personnel; personnel management policy (requirements for recruitment and dismissal, professional development, assessment of work quality, system of rewards). The audit firm sets and records the procedures to be applied to assure the compliance with ethical principles (honesty, objectivity, professional competency, confidentiality, professional behavior), and for identification and prevention of threats to its independence. The general procedures for acceptance are as follows: assessment of the firm's resources for engagement performance, assessment of the client's integrity, reaching agreement on the engagement terms and continuance of client relationship. The section "Human resources" of the internal standard contains the procedures for personnel recruitment, continuance of cooperation with personnel, assessment of their competence and capacities to perform auditing engagements, use of disciplinary actions (if necessary). The section "Engagement performance" of the internal standard includes the description of policies and procedures for collecting sufficient and acceptable audit evidence in order to form the auditor' opinion about financial statements. For companies with public significance, in conformity with the law, the review of auditor's report is envisaged, and the structure of the reviewer's report is proposed. Once the reviewer's report is received by the audit firm and differences in opinions are settled, the auditor's report on financial statements, the supplementary report to the auditing committee, and the report to supervisory bodies (if necessary) will be made. The section "Monitoring of the internal standard" includes recording of procedures for monitoring of quality control system (the existence of quality control system and its compliance with current legal requirements, International Standards of Auditing and internal standards). Use of the internal standard "The Policy and Procedure of the System for Internal Quality Control of Audit Services" can essentially increase the quality of auditing and other engagements on ensuring confidence and related services.

Key words: audit, quality of audit services, internal standards, professional ethics, related auditing services.

Approval of the new Law of Ukraine "On Accounting" [1] and the Law of Ukraine "On Audit of Financial Statements and Auditing" [2] has raised the problem related with quality assurance of auditing services as the most important one, which requires its urgent investigation and solution. It is related with: i) identification of companies with public significance

(C) O. E. Lubenchenko, 2019 and the interest of their owners, investors, regulators in reliable and impartial information on the financial condition, financial results, money and capital flows; (ii) the enhanced responsibility of auditing firms for the quality of audit procedures, collected evidences and audit reports made up on their basis. In view of this, auditing firms have to scrutinize legal requirements, International Standards of Auditing (ISA) and to start working on internal 
standardization in order to improve the system of internal control over the quality of audit services. Issues of audit control were investigated by foreign and domestic scientists: L. Verovska [3], S. Bychkova and O. Itihilova [4], V.Yemelin and M. Zhetova [5], O. Redko [6], N. Proskurina and V. Kovalenko [7], N. Shalimova [8], M. Vasyliuk [9] and others. The published reports of the Audit Chamber of Ukraine about the auditing performance show that although most part of the auditing firms exerted much effort to elaborate and implement the quality control system in audit, the external review of the quality control system was not passed by $23.2 \%$ of the firms in 2017 and in $19 \%$ in 2018 [10].

Creation of the body of public oversight over the auditing within the Oversight Council and Inspection on Quality Assurance in conformity with the Law of Ukraine "On Audit of Financial Statements and Auditing", and compliance with provisions of the domestic law require from auditing firms to take measures on adjusting the quality control system by improving the internal standards.

The study's objective is to create the internal standard "The Policy and Procedure of the System for Internal Quality Control of Audit Services", which is supposed to provide practical guidelines for auditing firms and help them comply with the requirements of the law on quality of audit and auditing services.

The system for quality control of auditing services, according to the International Standard on Quality Control 1 "Quality Control for Firms That Perform Audits and Reviews of Historical Financial Information, and Other Assurance and Related Services Engagements" (ISQC 1), has to consist of the following components: (i) leadership responsibilities for quality within the firm; (ii) ethical requirements; (iii) acceptance and continuance of client relationships and specific engagements; (iv) human resources; (v) engagement performance; (vi) monitoring [11].

As ISQC 1 contains general requirements to the quality control system, each auditing firm (referred to hereinafter as "the firm"), in view of its operation specificities, has to elaborate and approve the policy and procedures for quality control, and to ensure their documentation. The structure of the internal standard "The Policy and Procedure of the System for Internal Quality Control of Audit Services", elaborated in conformity with ISQC 1 , is shown in Table 1

Table 1

The structure of the internal standard "The Policy and Procedure of the System for Internal Quality Control of Audit Services"

\begin{tabular}{|c|c|c|}
\hline No & Contents & Explanations \\
\hline 1 & $\begin{array}{l}\text { Glossary of terminology in } \\
\text { the context of International } \\
\text { Standards of Auditing }\end{array}$ & $\begin{array}{l}\text { As ISA contains glossary of terminology, it is desirable to refer to ISA or } \\
\text { include the glossary in the preamble of the internal standard }\end{array}$ \\
\hline 2 & $\begin{array}{l}\text { Leadership responsibilities for } \\
\text { quality within the firm }\end{array}$ & $\begin{array}{l}\text { The components creating the proper environment for control should be } \\
\text { recorded: } \\
\text { - style and main principles of firm management; } \\
\text { - the organizational structure that will conform to the firm's statutory } \\
\text { documents and specialization; } \\
\text { - sharing of responsibility and authorities by approval of provisions on } \\
\text { units, job description etc. } \\
\text { - personnel management policy (requirements on recruitment and dis- } \\
\text { missal, professional development, work quality assessment, system of } \\
\text { rewards) [12] }\end{array}$ \\
\hline 3 & Ethical requirements & $\begin{array}{l}\text { The following policies and procedures should be recorded: } \\
\text { - observance of ethical principles (honesty, objectivity, professional } \\
\text { competence, confidentiality, professional behavior); } \\
\text { - identification and prevention of threats to the firm's independence, } \\
\text { including ones occurring in the firm's relationships with one client with } \\
\text { the share in the firm's income higher than 10\% of its total income; moni- } \\
\text { toring of threats to the firm's independence }\end{array}$ \\
\hline 4 & $\begin{array}{l}\text { Acceptance and continuance of } \\
\text { client relationships }\end{array}$ & $\begin{array}{l}\text { The following aspects should be recorded: general principles of engage- } \\
\text { ment acceptance (assessment of resources for engagement, the client's } \\
\text { integrity); principles of pricing; negotiation of engagement terms; terms } \\
\text { of continuance of client relationships; the sample contract sheet; the } \\
\text { contract for auditing services }\end{array}$ \\
\hline 5 & Human resources & $\begin{array}{l}\text { The following aspects should be recorded: principles of cooperation with } \\
\text { personnel; procedures for recruitment of new personnel; assessment of } \\
\text { their competence and capacities to carry out auditing engagements; dis- } \\
\text { ciplinary actions }\end{array}$ \\
\hline 6 & Engagement performance & $\begin{array}{l}\text { The following aspects should be recorded d: procedures for supervision } \\
\text { of the review process; the procedure for consulting when performing } \\
\text { engagement, authentication of differences in opinions; use of work of } \\
\text { invited experts; the procedures for review of the performed engagement; } \\
\text { classification of work documentation and measures to protect confiden- } \\
\text { tial information and preserve work documentation }\end{array}$ \\
\hline
\end{tabular}


Table 1, Continuation

\begin{tabular}{|c|c|c|}
\hline 6.1 & $\begin{array}{l}\text { Work documents on perfor- } \\
\text { mance of previous engagement } \\
\text { procedures }\end{array}$ & $\begin{array}{l}\text { Information on auditing engagement. } \\
\text { Information on client's company. } \\
\text { Information of the previous auditor. } \\
\text { Ethical principles of the personnel and the firm. } \\
\text { Appointment of an engagement team. } \\
\text { Calculation of the engagement budget (timing, human resources). } \\
\text { Acceptance }\end{array}$ \\
\hline 6.2 & $\begin{array}{l}\text { Work documents on planning } \\
\text { of auditing engagements }\end{array}$ & $\begin{array}{l}\text { Order on appointment of an engagement team. } \\
\text { Assessment of auditor risk. } \\
\text { Testing of the client's accounting policy. } \\
\text { Plan of client company accounts. } \\
\text { Review of the accuracy of computation of the estimated indicators. } \\
\text { Balances and turnovers on accounts. } \\
\text { Trial balance, report on financial results. } \\
\text { Computation of the materiality. } \\
\text { Assessment of risks of material misstatement resulting from fraud }\end{array}$ \\
\hline 6.3 & $\begin{array}{l}\text { Work documents on engage- } \\
\text { ment performance }\end{array}$ & $\begin{array}{l}\text { Overall strategy and detailed plan. } \\
\text { Special considerations on the first task. } \\
\text { Audit evidence. } \\
\text { Analysis of the client company's compliance with legal requirements. } \\
\text { Confirmation of the account balances (inquiries, analytical procedures) }\end{array}$ \\
\hline 6.4. & $\begin{array}{l}\text { Work documents on final pro- } \\
\text { cedures }\end{array}$ & $\begin{array}{l}\text { Adjustments of accounting estimates. } \\
\text { Systematization of deviations revealed. } \\
\text { Review of the events after the balance date. } \\
\text { Assessment of business continuity. } \\
\text { Written assurances. } \\
\text { Outcome documents (letter to management, supplementary report to } \\
\text { the auditing committee, auditor's report). } \\
\text { Transfer of the engagement results. } \\
\text { Forming work files on review }\end{array}$ \\
\hline 6.5 . & Other work documents & Documents received from third persons \\
\hline 7 & Monitoring & $\begin{array}{l}\text { Monitoring of the engagement performance. } \\
\text { Monitoring of the quality control system (existence and compliance of } \\
\text { the quality control system with the current legal requirements). } \\
\text { Reactions to appeals }\end{array}$ \\
\hline 8 & Appendices & Nomenclature of work documents \\
\hline
\end{tabular}

The section "Acceptance and continuance of client relationships" of the internal standard is extremely important, because the procedures proposed by the author in this section determine the firm's ability to accept a client's proposition, perform an engagement and receive a revenue.

As specified in paragraph 26 of ISQC 1, the firm shall accept a new engagement (or shall continue relationship with an existing client), if:

- it is able to perform an engagement, i. e. time, technical and human resources are available: the sufficient number of employees, including the ones recruited on contract basis and the ones implementing control measures in time of review; competencies of an engagement team regarding operation specifics of a business entity in the industry in question, including ones related to accounting and taxation; understanding of the goal and subject of audit. The experience of an engagement team is determined by (i) their involvement in analogous audit engagements; (ii) the availability of information about their continual professional development;

- it complies with the established ethical requirements;
- it has ascertained the client's honesty (test on fraud; this test, according to paragraph A20 of ISQC consists of: contacts with firms that render (or rendered before) professional accounting services to this client; contacts with third parties (lawyers, banks and other entities); search for information in databases and/or in Internet. All the information about the client's operation, obtained by an auditor, and information from third persons about the client's operation and honesty has to be recorded in the work document "Information on audit customer and its acceptance" (Table 2). When after the analysis of compliance with ethical principles, existing resources, operation specifics and customer's integrity the firm takes decision to withdraw from new engagement, this decision will be communicated by the firm leadership to the customer by letter made in paper or electronic form using electronic signature of the firm's director. The firm can withdraw from an engagement in time of auditing, if it has got information rendering further client relationship impossible. If so happens, then, in conformity with paragraph 28 of ISQC 1, professional and legal responsibility of the firm has to be scrutinized, as well as the possibility to withdraw 
Information on audit customer and its acceptance

\begin{tabular}{|c|c|c|}
\hline No & Information & Information source and recording \\
\hline 1 & Activities of audit customer & $\begin{array}{l}\text { Activities: manufacturing, trade, other (statute, } \\
\text { extraction from the Single State Register) }\end{array}$ \\
\hline 2 & $\begin{array}{l}\text { Number of branches (separate structural units), } \\
\text { their location and activities performed. Brief } \\
\text { description of activity objects. } \\
\text { Average number of personnel }\end{array}$ & $\begin{array}{l}\text { Information about branches: } \\
\text { A brief description of manufacturing, trade, services, } \\
\text { other activities, the number of employees ((statute, } \\
\text { extraction from the Single State Register, statistical } \\
\text { reports on the number of personnel and salaries) }\end{array}$ \\
\hline 3 & $\begin{array}{l}\text { Information about the existence of foreign eco- } \\
\text { nomic activities }\end{array}$ & $\begin{array}{l}\text { A brief description of exports and imports of goods, } \\
\text { works, services, including controlled transactions, } \\
\text { according to Article } 39 \text { of the Tax Code of Ukraine }\end{array}$ \\
\hline 4 & The existence of non-monetary and cash payments & Accounting records (accounting registers) \\
\hline 5 & $\begin{array}{l}\text { The existence of intermediate transactions: transac- } \\
\text { tions by commission agreements, by trust agree- } \\
\text { ments }\end{array}$ & Accounting records (accounting registers) \\
\hline 6 & $\begin{array}{l}\text { The facts of client managers' personal gain through } \\
\text { undervaluation of taxes, sales of business entity's } \\
\text { shares, receipt of bonuses and unsanctioned } \\
\text { rewards }\end{array}$ & Accounting records (accounting registers) \\
\hline 7 & $\begin{array}{l}\text { Ignoring of the internal control system by client's } \\
\text { managers or taking advantage of the internal con- } \\
\text { trol drawbacks }\end{array}$ & $\begin{array}{l}\text { Accounting records (accounting registers) (the exis- } \\
\text { tence of shortfalls, spoilage of inventory) }\end{array}$ \\
\hline 8 & \begin{tabular}{|l|} 
Accounting policy of a business entity and its spe- \\
cifics. Persons responsible for accounting and con- \\
trol of making financial, tax and statistical reports
\end{tabular} & $\begin{array}{l}\text { Company's statute and administrative documents, } \\
\text { including the order on accounting policy, documents } \\
\text { on inventory count }\end{array}$ \\
\hline 9 & $\begin{array}{l}\text { Rendering of auditing and other-than-auditing ser- } \\
\text { vices to the audited company }\end{array}$ & $\begin{array}{l}\text { Contracts with auditing firms, information on the } \\
\text { previous auditor (if any) }\end{array}$ \\
\hline \multicolumn{2}{|c|}{ The auditor's conclusion about the acceptability } & $\begin{array}{l}\text { Acceptance or withdrawal, name, father's name and } \\
\text { surname of a person taking the decision on client } \\
\text { relationship }\end{array}$ \\
\hline
\end{tabular}

from an engagement or withdraw from an engagement in parallel with breaking client relationship. This scrutiny should involve a discussion between customer's managers and highest executives of the firm. The discussion results need to be documented as a separate record of the meeting of representatives from the firm and the customer.

Acceptance is finished by signing the contract on auditing, with the final approval of engagement terms. The contract is made in written form. According to the Business Code of Ukraine (BCU), a business contract is considered as concluded, when the parties have reached agreement on its essential terms in a manner and form specified by the law. Essential are the terms either recognized as such by the law or considered as necessary for this category of contracts, as well as the terms on which agreement can be reached by request of either party. Given the provisions of Article 180 of BCU and ISA 200 "Overall Objective of the Independent Auditor, and the Conduct of an Audit in Accordance with International Standards on Auditing", the essential terms of an auditing contract are as follows:

- subject (task objective and scopes);

- contract value (amount and terms of payment);

- duration of contract and terms of review;

- responsibility of the firm;
- responsibility of a business enterprise whose financial reports are subject to auditing (a customer of auditing services);

- terms that have to be agreed by contract parties in conformity with the requirements of ISA and the current law (depending on the types of individual tasks);

- other terms recognized as essential by the parties' agreement.

In addition to these requirements on the materiality of terms, Article 7 of the Law of Ukraine "On Audit of Financial Statements and Auditing" requires that, apart from the contract subject and the responsibility of the parties, the scopes of auditing services and the other terms must be indicated, in accordance with the current law and ISA. The rights and obligations of the firm and the customer with respect to auditing services are specified in the contract according to the requirements of the Law of Ukraine "On Audit of Financial Statements and Auditing" and other regulatory acts. A customer has free choice of the firm considering the specifics of auditing of financial statements of companies with social significance. Customer's executives must create appropriate conditions for the firm, so that the auditing services could be rendered with high 
quality, and they are responsible for the authenticity of information given to an auditor for review.

The section "Human resources" is intended to ensure the conformity with the requirements of ISQC 1 on the sufficiency of firm's personnel for the engagement performance and their compliance with ethical requirements. The personnel are recruited by labor contracts or by civil contracts. For this purpose, the firm uses the standard contract form and administrative documents: staffing table, time sheets, order on employee admission by labor contract; form of employee data card (Order of the State Statistics Committee of Ukraine and the Ministry of Defense of Ukraine from 25.12.2009 No 495/656); job description. The employees in staff and the personnel recruited by civil contracts need to read the respective administrative documents and sign them.

The firm's policy on personnel competencies involves a number of procedures:

- testing of personnel in time of recruitment;

- annual testing as part of professional development;
- testing of work quality.

For this purposes, the internal standard includes sample tests that have to be updated each year.

The ways of professional development and improvement of professional competencies are as follows: professional training, non-stop professional education; training by recruiting personnel with higher skills to engagement teams or inviting consultants by organizing thematic seminars devoted to important issues of accounting, audit, taxation; discussions of important practical issues of accounting and tax records or auditing practices at these seminars; organization of monitoring of the current law; providing access to reference systems "LIHA-bukhalter", Hrosbukh", "Bukhalter 911"; purchase of special literature on issues of auditing, accounting, taxation, business and civil law. Testing of work quality of personnel has to be conducted annually, with its results recorded in the work document "Employee evaluation" (Table 3).

The working document "Employee evaluation"

Table 3

\begin{tabular}{|c|c|c|}
\hline \multicolumn{2}{|r|}{ Name, father's name, surname of a firm's employee } & \multirow{2}{*}{\begin{tabular}{|c|} 
Position \\
$\begin{array}{c}\text { Scores (maximal number } \\
\text { of } 100 \text { scores) }\end{array}$
\end{tabular}} \\
\hline No & Questions on evaluation & \\
\hline \multirow[t]{3}{*}{1} & Communications with colleagues: & 20 \\
\hline & Goodwill & \\
\hline & $\begin{array}{l}\text { A convincing manner of conveying own ideas about the subject of auditor's } \\
\text { attention }\end{array}$ & \\
\hline \multirow[t]{3}{*}{2} & Work skills / experience & 20 \\
\hline & The scopes of completed tasks in the plan & \\
\hline & Knowledge of auditing essentials and regulatory framework & \\
\hline \multirow[t]{4}{*}{3} & Organization of the auditor's job place & 20 \\
\hline & Keeping documentation in a proper manner & \\
\hline & Sharing of an auditor task according to its objective & \\
\hline & Effectiveness of use of work time & \\
\hline \multirow[t]{2}{*}{4} & Control & 20 \\
\hline & $\begin{array}{l}\text { Compliance with the firm's policy and procedures for quality control of auditing } \\
\text { tasks; annual testing for professional development }\end{array}$ & \\
\hline \multirow[t]{3}{*}{5} & Other qualities & 20 \\
\hline & Knowledge of information sources & \\
\hline & Propensity to creative thinking; adequacy of taken decisions & \\
\hline
\end{tabular}

If the firm's personnel fails to fulfill job functions (or fulfill them improperly), they can be subject to the following types of disciplinary actions: reprimand; reduction of bonuses; dismissal according to the Code of the Labor Laws of Ukraine. Each type of failure entails only one type of disciplinary action, which is announced by the order (directive) and delivered to an employee against receipt. A disciplinary action can be appealed by an employee in a manner specified in the current law. If the firm or its client is incurred material losses, or if the firm's reputation is discredited due to actions of the firm's personnel, its director is entitled to take a decision on bringing a claim to court for criminal prosecution of a guilty person.

The section "Engagement performance" includes the description of policies and procedures established by the firm in order to ascertain that the engagements are performed in conformity with professional standards, with reports made by the firm on the basis 
of sufficient and acceptable auditor evidence. These policies and procedures include:

- scrutiny of issues that are important for quality assurance of engagements;

- responsibility for oversight;

- responsibility for work review.

According to paragraph 34 of ISQC 1, the oversight of engagement involves:

- monitoring of the work progress by the engagement partner;

- assessment of competencies and capabilities of selected members of the engagement team by the engagement partner, to find out if members of the engagement team have sufficient time to do the work, if they understand the instructions given to them or if the work is carried out according to the plan;
- scrutiny of important issues by the engagement partner, occurring in time of the work, with adjusting the strategy or the plan of review in case of need (changing the assessment of auditor risk, which entails variations in the audit sample); issues requiring additional consultations due to differences in opinions or invitation of an expert.

The responsibility for oversight of the engagement performance is put on the engagement partner. Results of the scrutiny of contentious issues by the engagement partner have to be fixed in the work document "Record of the consultations on complicated or contentious issues" (Table 4).

Record of the consultations on complicated or contentious issues

Table 4

Record of the consultative meeting on complicated or contentious issues

Details of the engagements on which the consultation is held:

(Engagement type)

Customer: Name of customer of auditing services

Date of the beginning of review period:

Date of the end of review period:

According to the requirements of ISQC 1 and the internal standard for quality control of auditing services, the consultation is held for finding solutions to complicated or contentious issues arising in time of performing the above mentioned engagement.

Participants:

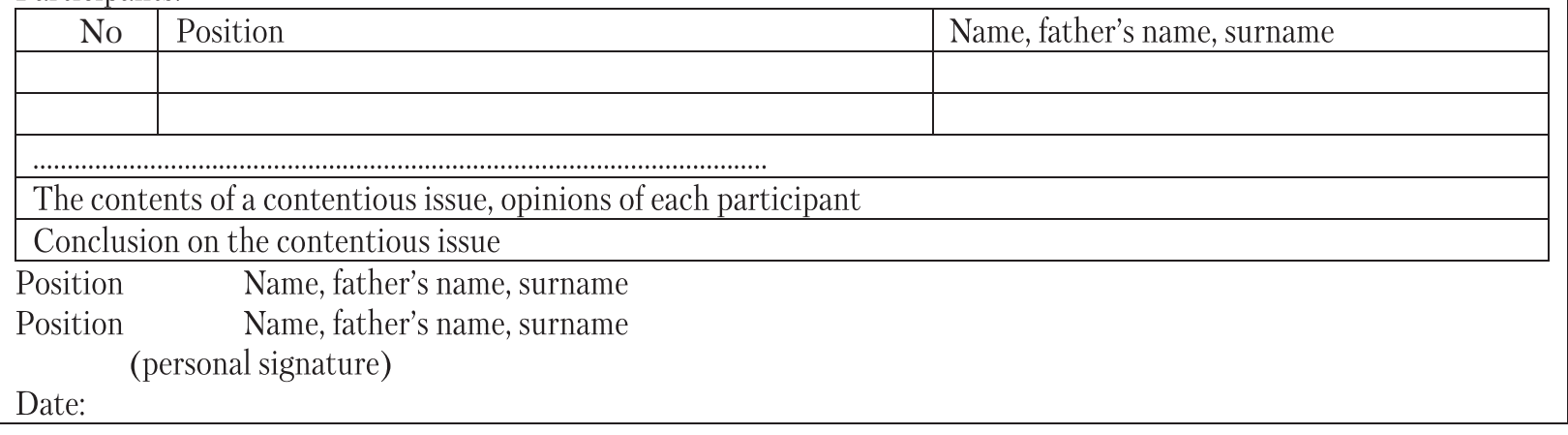

Quality control of an engagement is performed according to paragraphs A41, A 45 of ISQC 1 , in view of the need to assess:

- the character of engagement, including the degree of public concern with it; duration and scales of the review of engagement quality control;

- irregular circumstances; essential risks identified in time of engagement performance, and reactions;

- whether or not the review of engagement quality control is required by legal or regulatory acts;

- expressed opinions, including ones concerned with materiality and identified heavy risks;

- materiality and character of adjusted and unadjusted misstatements identified in time of engagement performance;

- issues that should be informed to management personnel and those assigned with highest authorities, and to other parties, such as regulatory bodies [11].

For companies with public significance, the review of auditor's report on financial statements is envisaged (Article 32 of the Law of Ukraine "On Audit of Financial Statements and Auditing"). The review is made by an auditor not engaged in the review of financial statements, which makes records of the review results. As the law does not specify a format for review document, a sample reviewer's report on auditing of financial statements is proposed in Table 5.

Once the reviewer's report is received and the differences in opinions settled, the reviewer's report on the financial statements, the supplementary report to the auditing committee, and the report to supervisory bodies (if necessary) will be provided for users. 
The work document "The reviewer's report on audit of financial statements

(name of the company which statements were subject to audit)"

\begin{tabular}{|c|c|c|}
\hline No & $\begin{array}{c}\text { Subject to reviewer's attention by Article } 32 \text { of } \\
\text { the Law of Ukraine } \\
\text { "On Audit of Financial Statements and } \\
\text { Auditing" }\end{array}$ & $\begin{array}{c}\text { Reviewer's actions and information disclosure } \\
\text { in the reviewer's report }\end{array}$ \\
\hline 1 & $\begin{array}{l}\text { Oral and written information provided by review- } \\
\text { er, auditor or key auditing partner, for confirma- } \\
\text { tion of essential judgments and main results of } \\
\text { performed auditing procedures and conclusions } \\
\text { made on the basis of these results, including the } \\
\text { conclusions in the auditing report and the supple- } \\
\text { mentary report for the auditing committee }\end{array}$ & $\begin{array}{l}\text { Scrutiny of work documents on auditing, references } \\
\text { in the report to the work documents that were scruti- } \\
\text { nized, and if the key partner's opinion conformed with } \\
\text { the reviewer's opinion (or recording of the justified dif- } \\
\text { ferences) }\end{array}$ \\
\hline 2 & Independence of the audit firm & $\begin{array}{l}\text { Scrutiny of the procedures on confirmation of the } \\
\text { auditing firm's independence, recording of whether or } \\
\text { not the procedures performed comply with ISQC } 1 \text { and } \\
\text { company's internal standards on quality assurance of } \\
\text { audit. }\end{array}$ \\
\hline 3 & $\begin{array}{l}\text { Considerable risks identified by auditor or by key } \\
\text { auditing partners when performing the engage- } \\
\text { ment on obligatory auditing of financial state- } \\
\text { ments, taken measures on control of identified } \\
\text { risks, and justification of the materiality of the } \\
\text { review }\end{array}$ & $\begin{array}{l}\text { Scrutiny of the procedures for assessment of auditor } \\
\text { risk and estimation of the materiality of review (select- } \\
\text { ed articles of financial statements), and recording of } \\
\text { whether or not the opinion of key partner comply with } \\
\text { the reviewer's one (or recording of justified differences) }\end{array}$ \\
\hline 4 & $\begin{array}{l}\text { Contacts with experts for consultations and } \\
\text { implementation of their recommendations }\end{array}$ & $\begin{array}{l}\text { Scrutiny of the work documents on involvement of } \\
\text { experts (if any), and recording of whether or not the } \\
\text { opinion of involved experts comply with the reviewer's } \\
\text { one (or recording of justified differences) }\end{array}$ \\
\hline 5 & $\begin{array}{l}\text { The character of misstatements and the scope } \\
\text { of adjusted and unadjusted unauthentic data in } \\
\text { financial statements, identified in time of auditing }\end{array}$ & $\begin{array}{l}\text { Scrutiny of the work documents that fix the differences } \\
\text { between the audit data and the data in financial state- } \\
\text { ments, justification of the key partner's opinion with } \\
\text { respect to the identified differences, recording of whether } \\
\text { or not the opinion of key partner comply with the } \\
\text { reviewer's one (or recording of justified differences) }\end{array}$ \\
\hline 6 & $\begin{array}{l}\text { Topics discussed with the auditing committee, } \\
\text { executives of the company which financial state- } \\
\text { ments are subject to review; topics that were dis- } \\
\text { cussed with competent bodies and, in some cases, } \\
\text { with other third persons }\end{array}$ & $\begin{array}{l}\text { Scrutiny of the work documents that fix the fact of } \\
\text { arrangement and results of meeting with the audit } \\
\text { customer, regulatory bodies (if any and if appropriate). } \\
\text { The reviewer's conclusions on the discussed issues }\end{array}$ \\
\hline 7 & $\begin{array}{l}\text { Draft auditing report and supplementary report } \\
\text { for the auditing committee }\end{array}$ & $\begin{array}{l}\text { The reviewer's conclusions on the information on the } \\
\text { above mentioned draft records }\end{array}$ \\
\hline
\end{tabular}

The section "Monitoring" is focused on recording of procedures for monitoring of quality control system (the existence of quality control system and its compliance with the requirements of the current law, the compliance of performed audits with ISQC 1, ISA and the internal standard on quality assurance). It also includes the procedures for reactions on addresses of users of auditing reports, regulatory bodies and other stakeholders.

To sum up, the internal standard "The Policy and Procedure of the System for Internal Quality
Control of Audit Services" helps the auditing firm effectively organize the auditing work, perform the auditing procedures in order to obtain sufficient and acceptable evidence required by an auditor for formulating the impartial opinion about financial statements, recording of the audit process; it enables for better satisfaction of information needs of users of auditing reports.

Further studies will be focused on elaboration of work documents on auditing of financial statements of companies with public significance.

\section{References}

1. Pro bukhhalterskyi oblik ta finansovu zvitnist v Ukraini: Zakon Ukrainy vid 16.07.1999 r. № 996-XIV, stanom na 01.01.2018 r. [On Accounting and Financial Reporting in Ukraine. Law of Ukraine of July 16, 1999 № 996-XIV as of November 16, 2018]. zakon4.rada.gov.ua. Retrieved from http://zakon4.rada.gov.ua/laws/ show/996-14 [in Ukrainian]. 
2. Pro audyt finansovi zvitnosti ta audytorsku diialnist: Zakon Ukrainy vid 21.12.2017 r. № 2258-VIII [On Audit of Financial Reporting and Audit Activities. Law of Ukraine of December 21, 2017 № 996-XIV]. zakon.rada.goz.ua. Retrieved from https://zakon.rada.gov.ua/laws/show/2258-19 [in Ukrainian].

3. Verovska, L. M. (2013). Otsenka i sovershenstvovanie systemy kontrolia kachestva auditorskikh usluh $\mathrm{v}$ Latvii. Finansovo-kredytna diialnist: problemy teorii ta praktyky - Financial and Credit Activity: Problems of Theory and Practice, 2 (15), 135-146. Retrieved from https://elibrary.ru/item.asp?id=21169296 [in Russian].

4. Bychkova, S. M., \& Ityhilova, E. Iu. (2015). Kontrol kachestva auditorskoi deiatelnosti [Quality Control of Audit Activities]. wererelitres.ru. Retrieved from https://www.litres.ru/svetlana-bychkova/kontrolkachestva-auditorskoy-deyatelnosti/ [in Russian].

5. Emelyn, V. N., \& Zheltova, M. F. (2013). Kontrol kachestva audita v Rossii: praktika i problemy osushchestvleniia [Audit quality control in Russia: practice and implementation issues]. Molodoi uchenyi Young Scientist, 7, 157-160. Retrieved from https://moluch.ru/archive/54/7305/ [in Russian].

6. Redko, O. Yu. (2009). Yakist audytorskykh posluh: filosofiia ta mifolohiia [Quality of audit services: philosophy and mythology]. Bukhhalterskyi oblik i audyt - Accounting and Audit, 1, 46-53 [in Ukrainian].

7. Proskurina, N. M., \& Kovalenko, V. P. (2010). Yakist audytorskykh posluh v Ukraini: realii ta perspektyvy [Auditing Services Quality in Ukraine: Realities and Perspectives]. Ekonomichnyi chasopys-XXI - Economic Annals-XXI, 9-10, 53-57. Retrieved from http://dspace.nbuv.gov.ua/bitstream/ handle/123456789/45567/11-Proskurina.pdf?sequence=1 [in Ukrainian].

8. Shalimova, N. S. (2009). Kontseptualni pidkhody do vyznachennia yakosti audytu [Conceptual Approaches to Audit Quality Determination]. Актуальні проблеми економіки - Current Problems of the Economy, 5 (95), 237-248. Retrieved from http://www.stattionline.org.ua/ekonom/34/2977-konceptualni-pidxodi-do-viznachennya-yakosti-auditu.html [in Ukrainian].

9. Vasyliuk, M. M. (2014). Teoretyko-metodychni ta praktychni zasady zabezpechennia vnutrishnoho kontroliu yakosti audytorskykh posluh/ [Theoretical-Methodological and Applied Principles of Providing Internal Control of Audit Services Quality]. Вісник Чернігівського державного технологічного університету. Серія "Економічні науки" - Bulletin of Chernihiv State Technological University. Series "Economic Sciences", 3, 266-269. Retrieved from https://economic-vistnic.stu.cn.ua/index.pl?task=arcls\&id=1359 [in Ukrainian].

10. Uzahalnena informatsiia pro stan audytorskoi diialnosti v Ukraini [Summarized Information on the State of Audit Activity in Ukraine]. wrere.apu.net.ua. Retrieved from https://www.apu.net.ua/1165-zvitapu-2017 [in Ukrainian].

11. Mizhnarodni standarty kontroliu yakosti, audytu, ohliadu, inshoho zavdannia z nadannia vpevnenosti ta suputnikh posluh [Handbook of International Quality Control, Auditing, Review, Other Assurance, and Related Services Pronouncements]. wrere.apu.net.ua. Retrieved from https://www.apu.net.ua/attachments/ar ticle/1151/2017_\%D1\%87\%D0\%B0\%D1\%81\%D1\%82\%D1\%8C1.pdf [in Ukrainian].

12. Alhorytm pobudovy systemy kontroliu yakosti dlia novostvorenoho subiekta audytorskoi diialnosti [An Algorithm for Building a Quality Control System for a Newly Created Audit Entity]. wrere.apu.com.ua. Retrieved from https://www.apu.com.ua/wp-content/uploads/2019/03/Alhorytm-pobudovy-SKIa.pdf [in Ukrainian].

\section{О. Е. Лубенченко,}

доктор економічних наук, доцент,

завідувач Національного центру обліку та аудиту,

Національна академія статистики, обліку та аудиту,

E-mail: olga.lubenchenko@gmail.com

ORCID: https://orcid.org/0000-0002-4209-8929

\section{Внутрішньофірмовий стандарт "Політика та процедури системи внутрішнього контролю якості аудиторських послуг"}

Нові Закони “Про бухгалтерський та фінансову звітність в Україні" та “Про аудит фінансової звітності та аудиторську діяльність” вимагають від аудиторського загалу підвищення рівня відповідальності за результати аудиту. Створення Органу суспільного нагляду за аудиторською діяльністю потребує постійного удосконалення системи внутрішнього контролю шляхом упровадження внутрішньофірмових стандартів. У статті представлено порядок розробки та основні елементи внутрішньофірмового стандарту “Політика та процедури системи внутрішнього контролю якості аудиторських послуг”. Структура внутрішньофірмового стандарту включає такі розділи: глосарій термінів; відповідальність керівництва за якість в аудиторській фірмі; етичні вимоги; прийняття завдань та продовження співпраці з клієнтом; людські ресурси; виконання завдання (робоча документація з виконання попередніх процедур за завданням, з планування та виконання аудиторських завдань, завершальні процедури, інша 
робоча документація), моніторинг системи контролю якості та окремих завдань, додатки. Для розуміння Міжнародних стандартів аудиту в преамбулі до внутрішньофірмового стандарту доречним $\epsilon$ наведення основних понять та визначень. Важливим є документування питань, що створюють відповідне середовище контролю: стиль і основні принципи управління аудиторською фірмою; організаційна структура аудиторської фірми та їі спеціалізація; розподіл відповідальності та повноважень управлінського та іншого персоналу; політика управління персоналом (вимоги до прийому та звільнення, підвищення кваліфікації, оцінки якості роботи, системи заохочень). Аудиторська фірма визначає та документує процедури, що застосовуються для забезпечення дотримання етичних принципів (чесність, об'єктивність, професійна компетентність, конфіденційність, професійна поведінка); виявлення загроз незалежності та запобігання таким загрозам. Загальні процедури прийняття завдання є такими: оцінка ресурсів аудиторської фірми для виконання завдання, оцінка чесності клієнта, узгодження умов завдання та продовження співпраці з клієнтом. Розділ “Людські ресурси” внутрішньофірмового стандарту містить процедури набору персоналу, продовження співпраці із ним, оцінку його компетентності, можливостей виконувати аудиторські завдання, застосування дисциплінарних стягнень (за необхідності). Розділ “Виконання завдавання" стандарту включає опис політики та процедур для збирання достатніх і прийнятних аудиторських доказів з метою формування аудиторської думки щодо фінансової звітності. Для підприємств, що становлять суспільний інтерес, згідно з законодавством передбачено рецензування звіту аудитора, запропоновано структуру звіту рецензента. Після отримання аудиторською фірмою звіту рецензента та врегулювання розбіжностей у думках формується звіт аудитора щодо фінансової звітності, додатковий звіт аудиторському комітету, звіт до органів нагляду (за необхідності). Розділ "Моніторинг" включає документування процедур моніторингу системи контролю якості (наявність та відповідність системи контролю якості чинним законодавчим вимогам, Міжнародним стандартам аудиту та внутрішньофірмовим стандартам). Застосування внутрішньофірмового стандарту "Політика та процедури системи внутрішнього контролю якості аудиторських послуг” значною мірою підвищить якість аудиту, інших завдань з надання впевненості та супутніх послуг.

Ключові слова: аудит, якість аудиторських послуг, внутрішньофірмовий стандарт, професійна етика, супутні аудиторські послуги.

Bibliographic description for quoting:

Lubenchenko, O. E. (2019). The Internal Standard "The Policy and Procedure of the System for Internal Quality Control of Audit Services". Statystyka Ukrainy - Statistics of Ukraine, 3, 107-115. Doi: 10.31767/su. 3(86)2019.03.12.

Бібліографічний опис для цитування:

Лубенченко О. Е. Внутрішньофірмовий стандарт “Політика та процедури системи внутрішнього контролю якості аудиторських послуг” (публікується англійською мовою) // Статистика України. 2019. № 3. C. 107-112. Doi: 10.31767/su. 3(86)2019.03.12. 